\author{
A.Zh. Sarsenbekova ${ }^{1}$, A.I. Khalitova ${ }^{1}$, T.E. Klimova ${ }^{2}$, T.O. Khamitova ${ }^{1}$, \\ G.K. Kudaibergen ${ }^{1}$, I.V. Figurinene ${ }^{3}$, A.T. Medeshova ${ }^{3}$, R.K. Sotchenko ${ }^{3}$ \\ ${ }^{1}$ E.A. Buketov Karaganda State University, Kazakhstan; \\ ${ }^{2}$ National Autonomous University of Mexico, Mexico; \\ ${ }^{3}$ Karaganda Medical University, Kazakhstan \\ (E-mail: chem_akmaral@mail.ru)
}

\title{
Study of acid properties of new polymeric complexes of maleic acid polymethylvinyl ether cross-linked by polypropylene glycol
}

\begin{abstract}
Dissociation course of polymethylvinyl ether of maleic acid cross-linked by polypropylene glycol (PMVE-MA with PPG) was investigated using classical potentiometric titration and colloid titration. It is assumed, that in the course of colloid titration monovalent counter-ions are replaced by the oppositely charged polycation, therefore it was determined the general concentration of anionic groups of hydrogel of polymethylvinyl ether of maleic acid cross-linked by polypropylene glycol. The apparent constant of dissociation (pseudo constant of dissociation) depends on the forming of the polyelectric complex but does not depend on the degree of dissociation. While it is known that potentiometric titration are determined by the apparent constant of dissociation that decreased simultaneously with the increase of the dissociation degree. Protons releasing from acid groups of hydrogel of polymethylvinyl ether of maleic acid cross-linked by polypropylene glycol leads to the formation of the complex with stronger cationic polyelectrolyte. Therefore, comparison of the results of potentiometric and colloid titration makes it possible to take in the information about the interrelation of acid characteristics of the surface of PMVE-MA with PPG and its functional properties. As a result we can define its application area for creation of new high-efficient composite material.
\end{abstract}

Keywords: polyelectrolyte, colloid titration, potentiometric titration, dissociation, hydrogel.

\section{Introduction}

In recent decades hydrogels are widely used for producing the composite materials, filtering elements for liquid and gaseous mediums, adsorbents used for cleaning the water from heavy and toxic metals and gathering the oil and oil-product, carriers of nanoparticles of different nature [1]. Their application area depends on physical and chemical compositions of polymers, and structural and acid-base surface characteristics of polymers [2]. It is necessary know the protolytic properties of polymer surfaces, the origin and the number of active cites for the determination the degree of adsorption activity and selectiveness of polymer materials. Inhomogenuity and high degree of dispersion of these materials make it more difficult to control the surface adsorptive and acid-base properties of polymer with the use of the method of surface analysis (the study of moistening (wetting) phenomenon by the use of test liquids).

At the present day adsorptive-chemical method mainly used for the defining surface acidity of finely dispersed materials [3]. This method is practically not used for the study of polymer materials surface. Considering that active sites of hydrogel surfaces are characterized with weak protolytic properties, it will be reasonable to use methods of potentiometric and colloid titration in non-aqueous or mixed solvents in order to estimate their quantity and values of $\mathrm{pK}$ (these methods are capable to strengthen donor-acceptor properties).

The article is devoted to the experimental evaluation of apparent constant of dissociation (pseudo constant of dissociation) (pK) of hydrogel of PMVE-MA with PPG in water and aqueous organic media by the use of potentiometric and colloid titration.

\section{Experimental}

Hydrogel of polymethylvinyl ether of maleic acid, cross-linked by polypropylene glycol (PMVE-MA with PPG) was used as the object of the research:

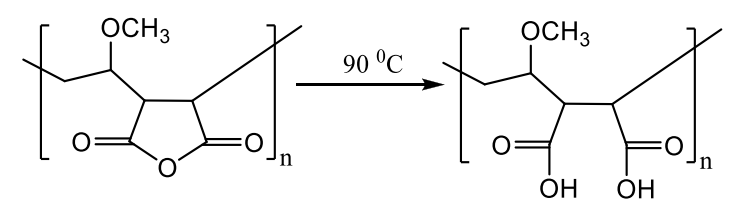


Poly(methyl-vinyl-co-maleic acid) or polymethylvinyl ether of maleic acid (PMVE-MA) were obtained by the hydrolysis of polymethylvinyl ether of maleic anhydride (PMVE-MAH). Process was performed on the unit composed of round-bottomed flask (volume $100 \mathrm{ml}$ ) and backflow condenser. Initial mixture was prepared from $0.65 \mathrm{~g}$ PMVE-MAH and $20 \mathrm{ml}$ distilled water. Hydrolysis was carried out during 2 hours at $90{ }^{\circ} \mathrm{C}$. Aqueuos solution of polypropylene glycol (PPG) was gradually added into obtained solution of polymethylvinyl ether of maleic acid (PMVE-MA) up to obtaining the homogeneous mixture. Excess water was removed by the use of rotary evaporator. Reaction mixture was solidified 24 hours at $80^{\circ} \mathrm{C}$. The gel of PMVE-MA with PPG [4] was obtained as a result of the esterification reaction among polymethylvinyl ether of maleic acid and polypropylene glycol:

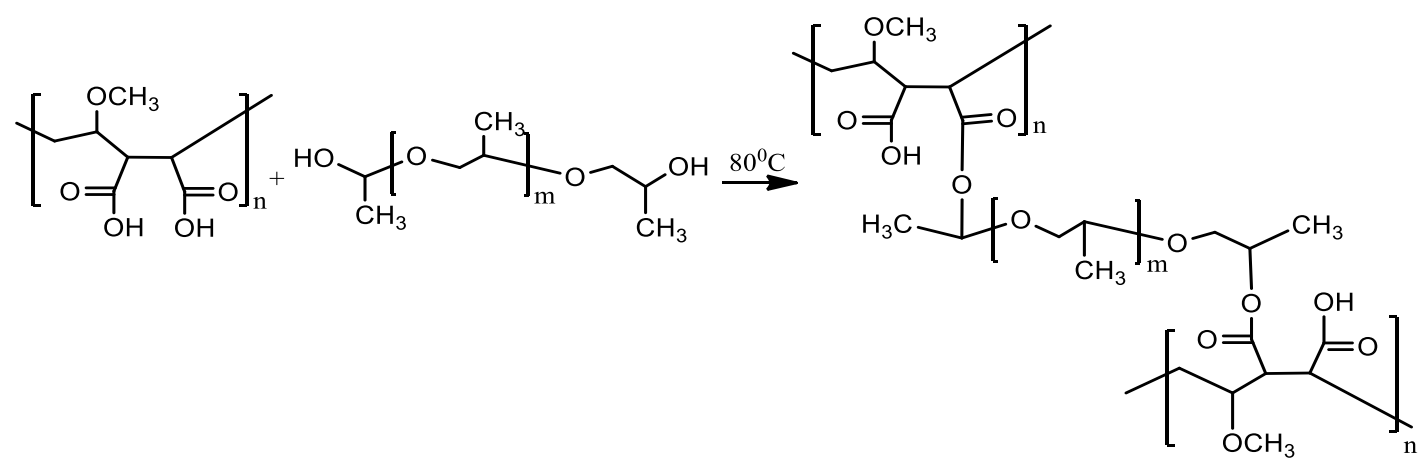

Potentiometric titration of hydrogel of PMVE-MA with PPG was performed in water and aqueous organic media $0.05 \mathrm{M}$ using the $\mathrm{NaOH}$ solution in the presence of $0.1 \mathrm{M} \mathrm{NaCl}$ accurate within 0.001 units of $\mathrm{pH}$. The titration was carried out using «I-160MI» ionomer with the function of push-button controlled mixing. The temperature was kept constant at $22^{\circ} \mathrm{C}$. Ethyl alcohol and acetone were chosen as organic solvents for the purpose of intensification of acidic sites. These solvents are characterized by the more distinctive basic properties than water and their acidity scale span is longer (ethanol 19.5; acetone 32.5) and consequently the discriminating fineness (differentiating ability) is greater. Mixed solvent «water - ethyl alcohol» (70 \% by ethanol weight), «water - acetone» (70\% by acetone weight) is the most perspective solvent for the study the slightly acidic properties of carbonaceous resin (carboxylic cation exchange resin).

Colloid titration of hydrogel of PMVE-MA with PPG $0.05 \mathrm{M}$ was performed by the use of $\mathrm{NaOH}$ solution in the $0.1 \mathrm{M} \mathrm{NaCl}$ presence.

The curves of potentiometric and colloid titration and the dependency of $\mathrm{pK}_{a}$ on the degree of dissociation $\alpha_{D}$ for hydrogel of PMVE-MA with PPG were obtained.

\section{Results and Discussion}

With the aim to study the process of dissociation of polymethylvinyl ester of maleic acid, linked with polypropyleneglycole, we obtained the curves of potentiometric and colloid titration and dependence of $\mathrm{pK}_{a}$ on the degree of dissociation $\alpha_{D}$ for hydrogel.

The dependency of the dissociation degree $\alpha_{\mathrm{D}}$ of hydrogel of PMVE-MA with PPG in neutral medium $\left(\alpha_{\mathrm{N}}=0.96\right)$ on the polymer concentration $\mathrm{c}_{\mathrm{p}}$ are presented in Figure 1. The degree of weak acid dissociation $\alpha_{\mathrm{D}}$ was defined according to the equation 1 :

$$
\alpha_{\mathrm{D}}=\frac{\mathrm{c}_{A^{-}}}{\mathrm{c}_{A^{-}}+\mathrm{c}_{H A}}
$$

As can be seen in Figure 1, the dissociation level of the acid is decreased in presence of organic solvents, which is confirmed with constant values of autoprotolysis of these solvents (ethanol, aceton), as well as with values of dipole moment and dielectric capacity.

Dissociation of hydrogel of polymethylvinyl ester of maleic acid, linked with polypropyleneglycole, was studied by method of potentiometric titration as well (Fig. 2, $a, b$ and $c$ ). 


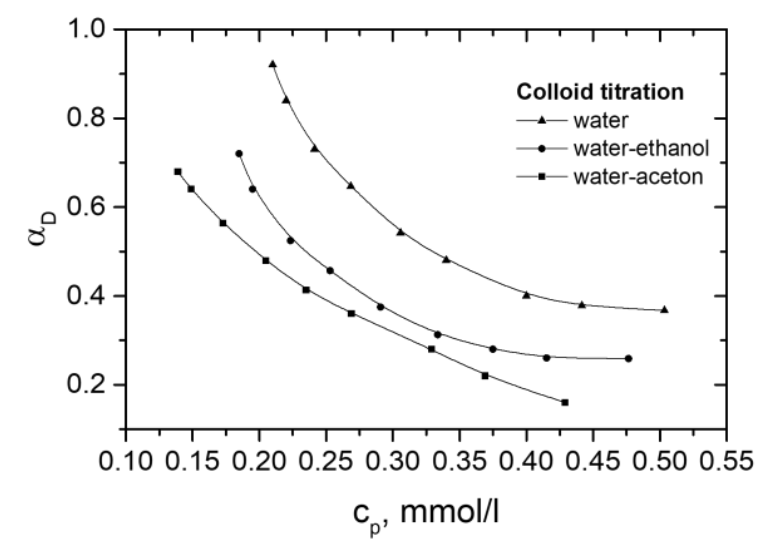

Figure 1. Dependence of dissociation level $\alpha_{D}$ on polymer concentration $c_{p}$
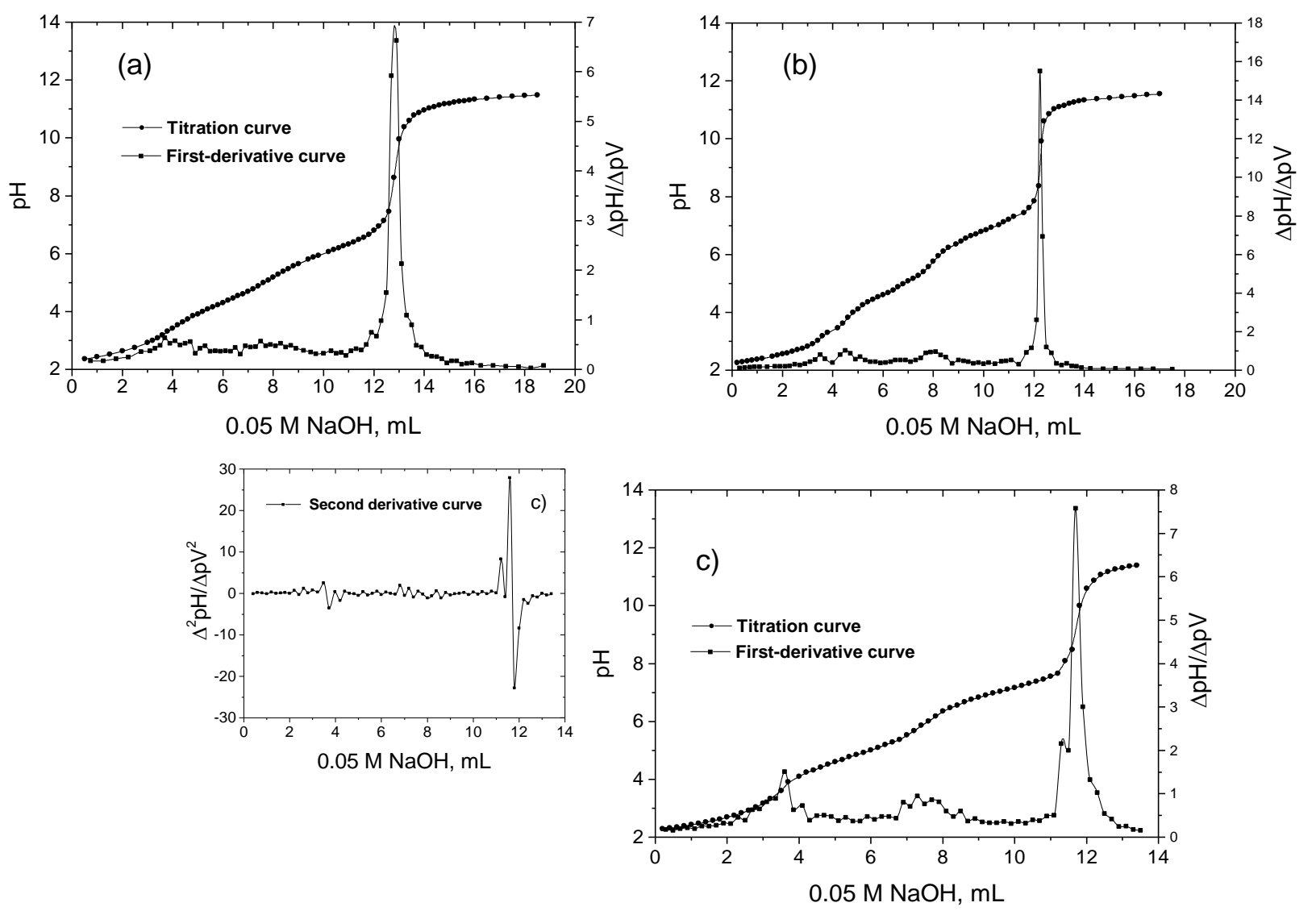

$a$ - water; $b$ - water - ethyl alcohol; $c$ - water - acetone

Figure 2. Integral and differential curves of titration of hydrogel of PMVE-MA with PPG in the presence of $\mathrm{NaCl}$ electrolyte, across different environments

According to the literature data water, acetone and ethanol have the following values of dipole moment $(\mu, D)$ and dielectric permeability $(\varepsilon)[5]\left(\right.$ at $\left.20{ }^{\circ} \mathrm{C}\right)($ Table 1$)$ :

\section{Dipole moment and dielectric permeability}

\begin{tabular}{|c|c|c|}
\hline Solvent & $\mu, \mathrm{D}$ & $\varepsilon$ \\
\hline Water & 1.8 & 78.5 \\
\hline Ethanol & 1.7 & 24.3 \\
\hline Acetone & 2.7 & 20.7 \\
\hline
\end{tabular}


Figure $2 a$ presents the titration curve of hydrogel of PMVE-MA with PPG, which functional groups are entirely protonated by the solvent of sodium hydroxide in aqueous media. As can be seen in Figure $2 a$, the differential curve has poorly resolved jumps of titration. The same dependency was obtained for the titration curves of hydrogel in water-ethanol mixtures (Fig. $2 b$ ). Replacing ethanol in the water-organic mixture to acetone being the less polar solvent we obtain the titration curves (Fig. $2 c$ ) that significantly differ, in the case of using the most polar solvent jump of titration will be sharper.

Addition of organic solvents decreases the level of dissociation, and thus charge quantity of macromolecule is decreased as well, and its shape is changed to nodular one. Here is cumulative effect in increase of availability of ionogenic groups and decrease of steric factor.

Observed indexes $\mathrm{pH}$ are graphically determined depending on neutralization degree $\alpha_{\mathrm{N}}$, which has been calculated according to the equation 2 :

$$
\alpha_{\mathrm{N}}=\frac{\mathrm{c}_{\mathrm{NaOH}}}{\mathrm{c}_{\mathrm{p}}},
$$

where $\mathrm{c}_{\mathrm{NaOH}}$ is the concentration of added titrating solution, and $\mathrm{c}_{\mathrm{p}}$ is the concentration of polymer in functional groups equivalent.

Both types of concentration are adjusted taking into dilution procedure. Taking into the consideration the simultaneous change of the titration curves and the decrease of ionic strength, it was assumed that there is the influence of electrostatic interaction (Coulomb interaction) as it was noted by authors of the work [6].

The degree of dissociation $\alpha_{D}$ was estimated according to the equation 3:

$$
\alpha_{\mathrm{D}}=\alpha_{\mathrm{N}}+\frac{\mathrm{c}_{\mathrm{H}_{3} \mathrm{O}^{+}}-\mathrm{c}_{\mathrm{OH}^{-}}}{\mathrm{c}_{\mathrm{p}}}
$$

where $\alpha_{N}$ is the neutralization degree and $c_{p}$ is the total concentration of hydrogel of PMVE-MA with PPG in functional groups equivalent.

Concentration of hydroxonium $\mathrm{c}_{\mathrm{H}_{3} \mathrm{O}^{+}}$was obtained from measured $\mathrm{pH}$. Concentration of hydroxide $\mathrm{c}_{\mathrm{OH}^{-}}$ was estimated using this value from ionic product of water $\mathrm{K}_{\mathrm{w}}\left(\mathrm{K}_{\mathrm{w}}=1.01 \times 10^{-14} \mathrm{~mol}^{2} / \mathrm{L}^{2}\right.$ at $\left.22{ }^{\circ} \mathrm{C}\right)$.

On the titration curves (Fig. 3) we can see the jumps corresponding to double-stage dissociation of hydrogel of PMVE-MA with PPG. The degree of dissociation $\alpha_{\mathrm{D}}$ increases along with growth of $\mathrm{pH}$.

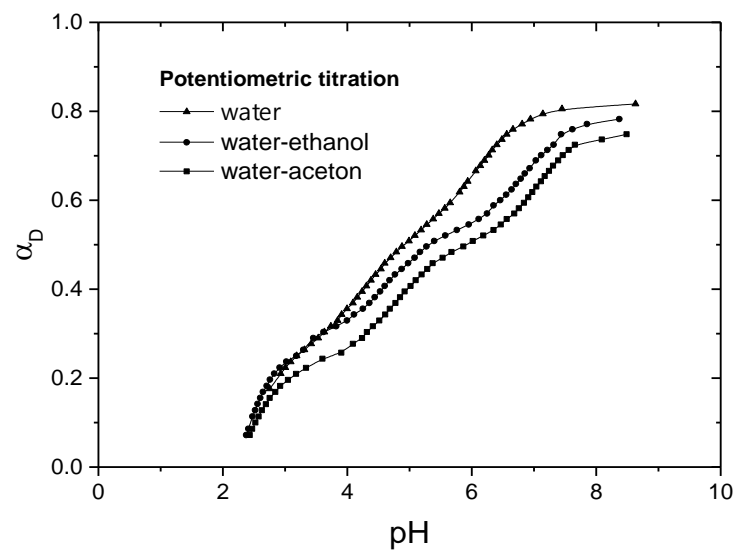

Figure 3. Dependence $\mathrm{pH}$ on the neutralization degree $\alpha_{\mathrm{N}}$ of hydrogel of PMVE-MA with PPG in the presence of $0.1 \mathrm{M} \mathrm{NaCl}$ determined by the potentiometric titration

In Figures 4 and 5 experimental data of potentiometric titration of hydrogel of PMVE-MA with PPG were presented as the functions of apparent constant of dissociation (pseudo constant of dissociation) $\mathrm{pK}$ on the degree of dissociation $\alpha_{\mathrm{D}}$. They were calculated according to Henderson-Hasselbach equation (equation 4) at the values of dissociation degree $\alpha_{\mathrm{D}}\left(0 \leq \alpha_{\mathrm{D}} \leq 1\right)$ and according to Lifson-Katchalsky theory (equation 5).

$$
\mathrm{pK}=\mathrm{pH}-\log \frac{\alpha_{\mathrm{D}}}{1-\alpha_{\mathrm{D}}} ;
$$




$$
\mathrm{pK}=\mathrm{pK}_{0}+\Delta \mathrm{pK}\left(\alpha_{\mathrm{D}}\right),
$$

where $\mathrm{K}_{0}$ - ionization constant of functional groups of the polymer, and $\Delta \mathrm{pK}\left(\alpha_{\mathrm{D}}\right)$ represents the contribution of electrostatic interaction (Coulomb interaction) of functional groups. It can be determined using the integration of the area under the curve $\mathrm{pK}-\mathrm{f}(\alpha)$.
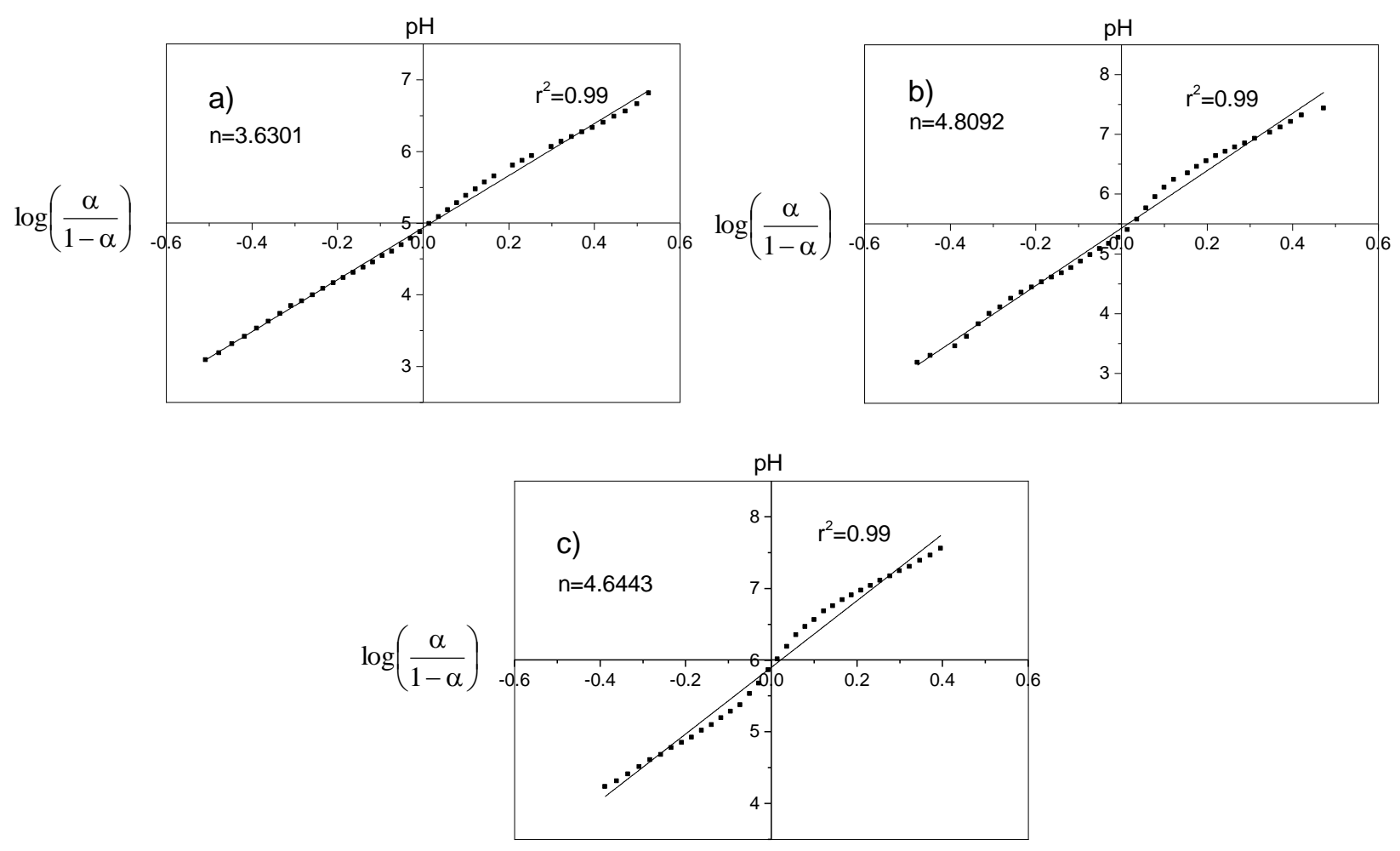

Figure 4. Curves of Henderson-Hasselbach for potentiometric titration of hydrogel PMVE-MA with PPG in presence of electrolyte $\mathrm{NaCl}$, in different media: a) water; b) water-ethyl alcohol; c) water-acetone

The apparent constant of dissociation (pseudo constant of dissociation) pK for hydrogel of PMVE-MA with PPG depends on the degree of dissociation $\alpha_{\mathrm{D}}$ evaluated according to the data of potentiometric and colloid titration (Fig. 5).

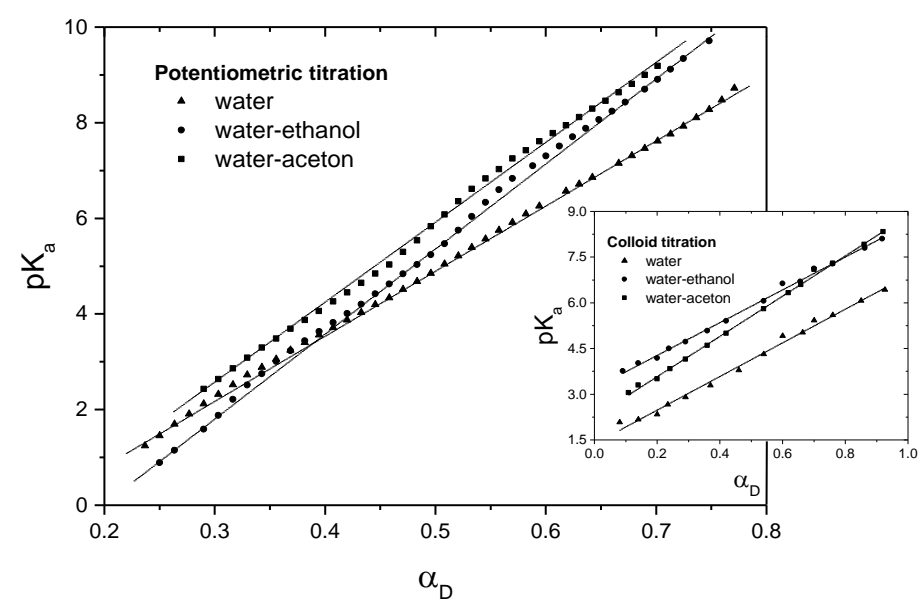

Figure 5. Dependency $p K$ on the degree of dissociation $\alpha_{\mathrm{D}}$ for hydrogel of PMVE-MA with PPG in the presence of $\mathrm{NaCl}$ obtained by the potentiometric and colloid titration

Consequently, surface acid sites of hydrogel of PMVE-MA with PPG can identified as carboxylic groups. This is confirmed by the results of IR-spectroscopy of hydrogel of PMVE-MA with PPG. In infra-red spectrum 
absorption bands have been found in the areas of $1712 \mathrm{~cm}^{-1}$ and $1640 \mathrm{~cm}^{-1}$. They are corresponding to valent asymmetrical and symmetrical oscillations (vibrations) of carboxylic group $\mathrm{C}=\mathrm{O}$ [7].

The aim of the research was the definition of apparent constant of dissociation (pseudo constant of dissociation) $K^{\#}$ of hydrogel of PMVE-MA with PPG according to the experimental data of colloid titration. For this purpose it was performed the computation according to equation system used for mathematical processing of the titration curves of the monobasic weak acid (HA) by $(\mathrm{NaOH})$ strong base. Using these equations we determined the dissociation constant of weak acid according to mass action law (Guldberg and Waage's Law of Mass Action) (equation 6), ionic product of water (equation 7), condition of electrical neutrality (equation 8) and the expression for the mass balance (equation 9) $[8,9]$.

$$
\begin{gathered}
\mathrm{K}_{a}=\frac{\mathrm{c}_{H_{3} O} \cdot \mathrm{c}_{A^{-}}}{\mathrm{c}_{H A}} ; \\
\mathrm{K}_{w}=\mathrm{c}_{H_{3} O^{+}} \cdot \mathrm{c}_{O H^{-}} ; \\
\mathrm{c}_{H_{3} O^{+}}+\mathrm{c}_{\mathrm{Na}^{+}}=\mathrm{c}_{O H^{-}}+\mathrm{c}_{A^{-}} ; \\
\mathrm{c}_{A^{-}}+\mathrm{c}_{H A}=\mathrm{c}_{p} .
\end{gathered}
$$

After the transformation we obtain the cubic equation:

$$
\mathrm{c}_{\mathrm{H}_{3} \mathrm{O}^{+}}{ }^{3}+\mathrm{c}_{\mathrm{H}_{3} \mathrm{O}^{+}}{ }^{2}\left(\mathrm{c}_{\mathrm{Na}^{+}}+\mathrm{K}_{a}\right)+\mathrm{c}_{\mathrm{H}_{3} \mathrm{O}^{+}}\left(\mathrm{c}_{\mathrm{Na}^{+}} \mathrm{K}_{a}-\mathrm{c}_{p} \mathrm{~K}_{a}-\mathrm{K}_{w}\right)-\mathrm{K}_{a} \mathrm{~K}_{w}=0 .
$$

As $\mathrm{C}_{\mathrm{H}_{3} \mathrm{O}^{+}}{ }^{3} \gg \mathrm{K}_{a} \mathrm{~K}_{w}$ then the equation takes the following form:

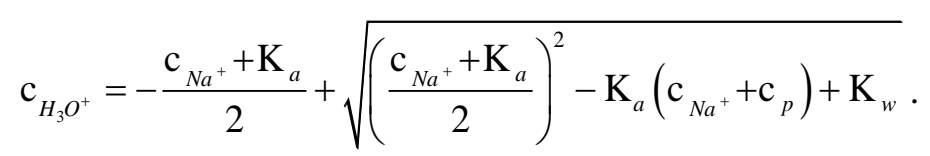

Replacing $\mathrm{c}_{\mathrm{Na}^{+}}=\alpha_{N} \cdot \mathrm{c}_{p}$ we obtain the dependence:

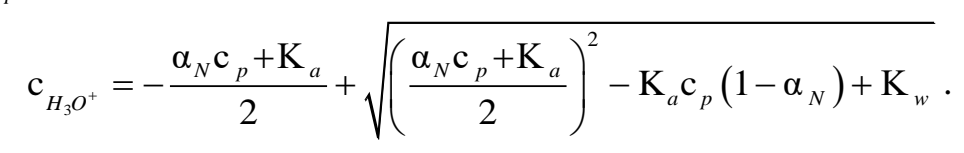

The degree of dissociation $\alpha_{\mathrm{D}}$ for hydrogel of PMVE-MA with PPG and the apparent constant of dissociation (pseudo constant of dissociation) $\mathrm{K}_{a}$ depending on $\mathrm{c}_{\mathrm{p}}$ and $\alpha_{\mathrm{N}}$ were estimated according to the equations 12 and 3 (Table 2).

Table 2

Value of pK $a$ and $n$ for hydrogel PMVE-MA with PPG at $\mathrm{t}=25^{\circ} \mathrm{C}$ in different media

\begin{tabular}{|c|c|c|c|}
\hline Solvent & $\mathrm{pK}_{\mathrm{a}}^{\#}$ & $n$ (equat. 4) & $\mathrm{pK}_{\mathrm{a}}$ \\
\hline Water & $1.4 \pm 0.1$ & 3.6301 & $1.8 \pm 0.1$ \\
\hline Water - Ethyl alcohol & $3.2 \pm 0.2$ & 4.8092 & $3.4 \pm 0.1$ \\
\hline Water - Acetone & $2.3 \pm 0.1$ & 4.6443 & $2.5 \pm 0.2$ \\
\hline
\end{tabular}

Calculated values $\mathrm{pK}_{\mathrm{a}}^{\#}, \mathrm{pK}_{\mathrm{a}}$ and $n$ are represented in the Table 2. As can be seen, obtained results comply with each other well.

\section{Conclusions}

Dissociation indexes of the hydrohel of PMVE-MA with PPG were determined by the potentiometric titration in water and water-organic medium. Index of apparent constant of dissociation (pseudo constant of dissociation) $\mathrm{pK}$ depends on the change of dissociation degree $\alpha_{\mathrm{D}}$ for the studied polymer. It was necessary to extrapolate $\mathrm{pK}$ and $\alpha_{\mathrm{D}}=0$ for the purpose of determination of $\mathrm{pK}_{0}$.

Contrary to data of potentiometric titration, the apparent constant of dissociation (pseudo constant of dissociation) $\mathrm{pK}^{\#}$ was determined by the use of colloid titration with the oppositely charged polycation is essentially independent of the degree of dissociation $\alpha_{D}$. In the case of the hydrohel of PMVE-MA with PPG 
the results of colloid titration do not point on the presence of two different ionized groups. This is explained by the fact that in the process of titration the monovalent counter-ion entirely replaced into polycation. Therefore we can measure the general concentration of polyacids anionic groups in hydrogel. Using the dissociation constants determined by the colloid titration, it becomes possible to determine the degree of dissociation and properly the charge of hydrogel of PMVE-MA with PPG for the wide spectrum of concentrations and neutralization degree in the case if there will be the oppositely charged macromolecules or surfaces in them. This has importance for the practical use of hydrogels if there is the replacement of counter-ions (for example, in adsorption process).

\title{
References
}

1 Филиппова О.Е. «Восприимчивые» полимерные гели / О.Е. Филиппова // Высокомолекулярные соединения. - 2000. — T. 42, № 12. - C. 2328.

2 Буркеев М.Ж. Полигликольмалеинаты в реакциях радикальной сополимеризации: моногр. / М.Ж. Буркеев, Е.М. Тажбаев, А.Ж. Сарсенбекова. - Beau Bassin: LAP LAMBERT Academic Publishing, 2017. — 192 c.

3 Галаев И.Ю. «Умные» полимеры в биотехнологии и медицине / И.Ю. Галаев // Успехи химии. — 1995. — Т. 65 , № 5. - C. 505-524.

4 Burkeev M.Zh. Synthesis and investigation of copolymer properties on the basis of poly(ethylene glycol)fumarate and methacrylic acid / M.Zh. Burkeev, G.K. Kudaibergen, Ye.M. Tazhbayev et al. // Bulletin of the Karaganda University. Ser. Chemistry. 2019. - No. 1(93). - P. 32-38.

5 Торопцева А.М. Лабораторный практикум по химии и технологии высокомолекулярных соединений / А.М. Торопцева, К.В. Белогородская, В.М. Бондаренко. - М.: Химия, 1972. - 223 с.

6 Быкова Л.Н. Кислотно-основные равновесия в среде амфипротонных растворителей и потенциометрическое титрование / Л.Н. Быкова, С.И. Петров // Успехи химии. - 1972. - Т. 42. - С. 2065-2093.

7 Nagasawa M. Potentiometric titration of stereoregular polyelectrolytes / M. Nagasawa, T. Murase, K. Kondo // J. Phys. Chem. - 1965. - Vol. 69. - P. 4005-4012.

8 Казицына Л.А. Применение ИК-, УФ-, ЯМР-спектроскопии в органической химии: учеб. пос. для вузов / Л.А. Казицына, Н.Б. Куплетская. — М.: Высш. шк., 1971. — 48 с.

9 Ebel S. Calculation of titration curves of weak acids and bases. Calculation of titration curves / S. Ebel // Arch Pharm. - 1969. - Vol. 302. - P. 856-862.

10 Lappan U. Apparent dissociation constants of polycarboxylic acids in presence of polycations / U. Lappan, U. Geißler, M. Oelmann, S. Schwarz // Colloid Polym. Sci. — 2012. — Vol. 290. - P. 1665-1670.

\author{
А.Ж. Сарсенбекова, А.И. Халитова, Т.Е. Климова, Т.О. Хамитова, \\ Г.К. Кудайберген, И.В. Фигуринене, А.Т. Медешова, Р.К. Сотченко
}

\section{Полипропиленгликольмен тігілген, малеин қышқылының полиметилвинилді эфирінің жаңа полимерлік кешендерінің қышқылдық қасиеттерін зерттеу}

\begin{abstract}
Полипропиленгликольмен тігілген, малеин қышқылының полиметилвинил эфирінің (ППГ-мен ПМВЭМҚ) диссоциациясының барысы мынадай әдістермен зерттелді: классикалық потенциометриялық титрлеу және коллоидтық титрлеу. Коллоидты титрлеу барысында бірвалентті кері иондар қарсы зарядталған поликатионмен ауыстырылды, осылайша полипропиленгликольмен тігілген малеин қышқылының полиметилвинил эфирінің негізіндегі гидрогелінің аниондық топтарының жалпы концентрациясы анықталды. Диссоциацияның көрінетін константасы бұл ретте полиэлектрлік кешеннің қалыптасуына байланысты болады, алайда диссоциация дәрежесіне байланысты емес. Бұл орайда потенциометриялық титрлеу диссоциация деңгейінің өсуімен бір мезгілде азайтылатын диссоциацияның көрінетін константасын анықтауға болатыны белгілі. Полипропиленгликольмен тігілген, малеин қышқылының полиметилвинил эфирінің қышқылы негізіндегі гидрогельдің қышқылдық топтарынан протондарды босату қатты катионды полиэлектролиті бар кешенді қалыптастыруға алып келді. Осылайша, потенциометриялық және коллоидтық титрлеу нәтижелерін салыстыру ППГ-мен тігілген ПМВЭ-МҚ беттерінің қышқылдық сипаттамаларының және оның функционалдық қасиеттерімен өзара байланысы туралы ақпарат алуға мүмкіндік береді. Осының арқасында жаңа, тиімділігі жоғары композициялық материалдарды жасау мақсатында оны қолдану аймағын анықтау мүмкіндігі ашылды.
\end{abstract}

Кілт сөздер: полиэлектролит, коллоидті титрлеу, потенциометриялық титрлеу, диссоциация, гидрогель. 


\title{
А.Ж. Сарсенбекова, А.И. Халитова, Т.Е. Климова, Т.О. Хамитова, Г.К. Кудайберген, И.В. Фигуринене, А.Т. Медешова, Р.К. Сотченко \\ Исследование кислотных свойств новых полимерных комплексов полиметилвинилового эфира малеиновой кислоты, сшитого полипропиленгликолем
}

\begin{abstract}
Ход диссоциации полиметилвинилового эфира малеиновой кислоты, сшитого полипропиленгликолем (ПМВЭ-МК с ППГ), был исследован методами классического потенциометрического титрования и коллоидного титрования. Предположено, что в ходе коллоидного титрования одновалентные противоионы заменяются противоположно заряженным поликатионом, таким образом, определяется общая концентрация анионных групп гидрогеля полиметилвинилового эфира малеиновой кислоты, сшитого полипропиленгликолем. Кажущаяся константа диссоциации при этом зависит от формирования полиэлектрического комплекса, но не связана со степенью диссоциации. Как известно, потенциометрическим титрованием определяют кажущуюся константу диссоциации, которая уменьшается одновременно с ростом степени диссоциации. Высвобождение протонов из кислотных групп гидрогеля полиметилвинилового эфира малеиновой кислоты, сшитого полипропиленгликолем, приводит к формированию комплекса с более сильным катионным полиэлектролитом. Следовательно, сравнение результатов потенциометрического и коллоидного титрования позволяет получать информацию о взаимосвязи кислотных характеристик поверхности ПМВЭ-МК с ППГ и его функциональными свойствами. Благодаря этому открывается возможность определения области его применения для создания новых высокоэффективных композиционных материалов.
\end{abstract}

Ключевые слова: полиэлектролит, коллоидное титрование, потенциометрическое титрование, диссоциация, гидрогель.

\section{References}

1 Filippova, O.E. (2000). «Vospriimchivye» polimernye heli [Responsive polymer gels]. Vysokomolekularnye soedineniia Polymer Science, 42, 12, 2328 [in Russian].

2 Burkeev, M.Zh., Tazhbaev, E.M., \& Sarsenbekova, A.Zh. (2017). Polihlikolmaleinaty v reaktsiiakh radikalnoi sopolimerizatsii [Polyglycol maleate in radical polymerization reaction]. Beau Bassin: LAP LAMBERT Academic Publishing [in Russian].

3 Galaev, I.U. (1995). «Umnye» polimery v biotehnolohii i meditsine [Smart Polymers in Biotechnology and Medicine] Uspekhi khimii - Chemical Reviews, 65, 5, 505-524 [in Russian].

4 Burkeev, M.Zh., Kudaibergen, G.K., Tazhbayev, Ye.M. et al. (2019). Synthesis and investigation of copolymer properties on the basis of poly(ethylene glycol)fumarate and methacrylic acid. Bulletin of the Karaganda University. Ser. Chemistry, 1(93), 32-38.

5 Toroptseva, A.M., Belogorodskaia, K.V., \& Bondarenko, V.M. (1972). Laboratornyi praktikum po khimii i tekhnolohii vysokomolekuliarnykh soedinenii [Laboratory Workshop on Chemistry and Technology of High Molecular Compounds]. Moscow: Khimiia [in Russian].

6 Bykova, L.N., \& Petrov, S.I. (1972). Kislotno-osnovnye ravnovesiia v srede amfiprotonnykh rastvoritelei i potentsiometricheskoe titrovanie [Acid-basic equilibrium in amphiprotic solvent medium and potentiometric titration]. Uspekhi khimii-Chemical Reviews, 42, 2065-2093 [in Russian].

7 Nagasawa, M., Murase, T., \& Kondo, K. (1965). Potentiometric titration of stereoregular polyelectrolytes. J. Phys. Chem., 69, $4005-4012$.

8 Kazitsyna, L.A., \& Kupletskaya, N.B. (1971). Primenenie IK-, UF-, YaMR-spektroskopii v orhanicheskoi khimii [Application of W-, IR-, NMR-spectroscopy in Organic Chemistry]. Moscow: Vysshaiia shkola [in Russian].

9 Ebel, S. (1969). Calculation of titration curves of weak acids and bases. Calculation of titration curves. Arch Pharm, 302, 856862.

10 Lappan, U., Geißler, U., Oelmann, M., \& Schwarz, S. (2012). Apparent dissociation constants of polycarboxylic acids in presence of polycations. Colloid Polym Sci., 290, 1665-1670. 